ISSN 1392-3196 / e-ISSN 2335-8947

Zemdirbyste-Agriculture, vol. 105, No. 1 (2018), p. 3-10

DOI 10.13080/z-a.2018.105.001

\title{
The impact of tillage, Ca-amendment and cover crop on the physical state of a clay loam soil
}

\author{
Aleksandras VELYKIS, Antanas SATKUS \\ Joniškèlis Experimental Station, Lithuanian Research Centre for Agriculture and Forestry \\ Joniškèlis, Pasvalys distr., Lithuania \\ E-mail: velykisalex@gmail.com
}

\begin{abstract}
Changes in the physical state of a clayey soil are determined by the soil type, soil moisture, weather conditions and tillage intensity. Possibilities to reduce tillage clayey soil have not been sufficiently investigated in Lithuania before. Research was carried out during 2014-2016 at the Joniškèlis Experimental Station of the Lithuanian Research Centre for Agriculture and Forestry on a clay loam (siltic, drainic), Endocalcary-Endohypogleyic Cambisol (CMg$n-w$-can) in the experiment, established in 2006. The aim of the present study was to evaluate the long-term effects of different tillage intensity as well as its combinations with supplementary agronomic practices (deep ploughing at $21-23 \mathrm{~cm}$ depth and shallow ploughless tillage at $10-12 \mathrm{~cm}$ depth as well as shallow ploughless tillage with incorporation of lime sludge and no-till in the autumn with a cover crop for winter mulch) on the indicators of soil physical state, investigated in a field pea crop. Ploughless tillage alone demonstrated the significantly higher soil water content before pre-sowing tillage in spring, higher soil dry bulk density, lower soil total porosity and soil water capacity before crop harvesting in topsoil; however, soil dry bulk density decreased, soil water capacity and soil total and air-filled porosity increased in the subsoil compared to deep ploughing. Incorporation of lime sludge (Ca-amendment) in the ploughless tillage plots resulted in higher soil water content before pre-sowing tillage, lower soil water content after crop emergence and before harvesting, higher air-filled porosity and amount of stable soil aggregates in topsoil, lower soil dry bulk density, higher total and air-filled porosity in subsoil before harvesting. Due to no-till in the autumn, with a cover crop for winter mulch, soil water content increased before pre-sowing tillage, it decreased after crop emergence and before harvesting in topsoil, soil dry bulk density decreased and total and air-filled porosity increased in subsoil; however, the amount of most agronomically valuable $(0.25-5.6 \mathrm{~mm})$ soil aggregates decreased in topsoil before harvesting compared to ploughing.
\end{abstract}

Key words: dry bulk density and porosity, no-till with mulch, ploughing, ploughless tillage, structure, water content and capacity.

\section{Introduction}

Heavy soils (clay loams and clays) are susceptible to compaction, as one of the most important type of human-induced physical soil degradation caused by intensive use of heavy machinery for field operations, especially under wet soil conditions (Keler et al., 2007; Riley et al., 2009). However, heavy soils characterised by poor physical properties by origin require more intensive tillage to maintain proper physical state, as proper conditions for grown crops. Clay loam and clay soils are typical of northern Lithuania. Therefore choice of suitable tillage systems is very important for clayey soils in the region. A search for other additional agronomic measures is also essential for maintenance of good soil physical state (Sustainable agriculture..., 2008).

Conservation agriculture is one of the strategies to eliminate soil degradation caused by compaction and erosion on agricultural fields. Tillage throughout soil condition affects soil sensitivity to climatic impacts both in the short and long term (Birkas et al., 2007). Reduced and no-tillage techniques together with crop rotation and crop residue management are the basis of conservation agriculture (Van den Putte et al., 2010). Conservation tillage can operate at shallower working depth than the conventional ploughing, increasing the work rate and reducing fuel consumption. Conventional tillage systems are generally more costly than conservation (reduced) tillage systems. On heavy soil, energy use for conventional ploughing is markedly higher compared to reduced non-inversion tillage and no-till. Success of conservation tillage systems depends on a number of factors including climatic conditions, soil type and organic matter content. When conservation (reduced) tillage is used over a long-time period, soil compaction occurs due to reduction in loosening depth (Morris et al., 2010; Van den Putte et al., 2010; Soane et al., 2012). Soil physical state is also affected by cover crop management.

Please use the following format when citing the article:

Velykis A., Satkus A. 2018. The impact of tillage, Ca-amendment and cover crop on the physical state of a clay loam soil. Zemdirbyste-Agriculture, 105 (1): 3-10 DOI 10.13080/z-a.2018.105.001 
Non-inversion tillage provides better opportunities for the use of various cover crop technologies to expand ecosystem functions. Cover crops with deep roots can loosen compacted soil (Bogužas et al., 2010; Crittenden et al., 2015; Rücknagel et al., 2016). In the late autumn, winter and early spring periods, when the soil is most sensitive to various environmental factors, cover crops are often the main source of living or frost killed mulch as a soil cover (Birkas et al., 2007; Derpsch et al., 2010).

The successful adoption of no-till systems is dependent on the choice and development of a cropping system that requires little soil disturbance. Diverse crop rotations including cereals, legumes and other crops are an important condition for success of no-till in different regions of Europe. No-till systems show the great adaptability to all kinds of climates, soils and cropping conditions. Therefore, this technology is practiced on soils varying from $90 \%$ sand to $80 \%$ clay. The rapid expansion of the area under no-till soils shows increasing interest in this technology (Derpsh et al., 2010; Soane et al., 2012).

Tillage system and crop rotation are substantial factors that affect the formation of soil aggregates. A good soil structure with stable aggregate fraction improves soil air and moisture exchange between the roots and soil environment (Al-Kaisi et al., 2014). Morris et al. (2010) reviewed adoption of non-inversion tillage systems in the United Kingdom and concluded that such tillage has to be carefully adopted to fit in with particular soil and climatic conditions for particular regions. On self-structuring clay soils the non-inversion system can be relatively well suited and allow for timely cultivations that reduce the risk of creating very dry, cloddy seedbed following ploughing wet soil. Caamendment, using liming material of various origins in combination with non-inversion tillage, is also a good agronomic practice to maintain the proper soil structure (Hontoria et al., 2016).

Studies carried out in various Lithuanian research institutions showed that the impact of reduced tillage in different Lithuanian soils varies considerably. The application of reduced ploughless tillage, especially no-till causes the differentiation of soil plough layer into an upper layer richer in nutrients and organic matter and a less rich lower layer, deterioration in the physical condition of the lower plough layer, wider spread of perennial weeds (Ožeraitiene, Čiuberkis, 2006; Romaneckas et al., 2009; Bogužas et al., 2010; Feiza et al., 2011). The application of reduced tillage for spring crops in clay loam soils often leads to a decrease in crop yield due to deterioration of soil physical and chemical properties (Sustainable agriculture..., 2008).

The objective of the current study is to establish the influence of deep ploughing, reduced ploughless tillage and its combination with the incorporation of lime sludge and no-till in autumn with a cover crop for winter mulch on soil physical state under field pea growing conditions.

The study hypothesises that reduced tillage, especially no-tillage, can lead to the deterioration in the physical condition of clayey soils in northern Lithuania, while the addition of lime sludge (Ca-amendment) in combination with ploughless tillage can help to prevent the harmful effects of reduced tillage.

\section{Materials and methods}

Site and soil description. Research was carried out during the period 2014-2016 at the Joniškèlis Experimental Station of the Lithuanian Research Centre for Agriculture and Forestry situated in the Northern part of Central Lithuania's lowland $\left(56^{\circ} 21^{\prime} \mathrm{N}, 24^{\circ} 10^{\prime} \mathrm{E}\right)$ in the experiment, established in 2006. The soil of the study site is Endocalcari-Endohypogleyic Cambisol (CMg- $n$ $w$-can) (siltic, drainic). Topsoil (0-25 cm) characteristics were as follows: texture - clay loam $(27.03 \pm 0.83 \%$ clay, $50.24 \pm 1.11 \%$ silt and $22.73 \pm 1.64 \%$ sand), humus content $-2.16 \pm 0.09 \%, \mathrm{pH}-6.6 \pm 0.2$; subsoil $(25-$ $35 \mathrm{~cm})$ texture - clay $(59.64 \pm 1.78 \%$ clay, $33.35 \pm 2.25 \%$ silt and $7.01 \pm 2.46 \%$ sand). During the last 40 years, the annual mean air temperature and total amount of precipitation were $6.1^{\circ} \mathrm{C}$ and $547.4 \mathrm{~mm}$, respectively.

Experimental design. The experiment examined thelong-termeffectsofconventional,reducedandno-tillage as well as the combinations of reduced and no-tillage with practices for soil improvement on soil physical state. The following tillage systems were investigated: 1) deep ploughing (DP) at 21-23 cm depth, 2) ploughless tillage (PT) at 10-12 cm depth, 3) ploughless tillage at 10-12 cm depth with lime sludge (Ca-amendment) incorporation $(\mathrm{PT}+\mathrm{LS})$ and 4) no-till in the autumn with a cover crop for winter mulch (NT $+\mathrm{WM})$. Research was conducted in the crop rotation: 1) field pea (Pisum sativum L. (Partim), 2) winter wheat (Triticum aestivum L.), 3) spring oilseed rape (Brasica napus L.) and 4) spring barley (Hordeum vulgare L.), which was spread over space and time. This article presents the soil physical state indicators, investigated in field pea crop. Cover crops were as follows: before field pea growing - a mixture of white mustard (Sinapis alba L.) and oilseed radish (Raphanus sativus L.), before spring oilseed rape growing - a mixture of field pea (Pisum sativum L. (Partim), common vetch (Vicia sativaL.) and blue lupine (Lupinus angustifolius L.), and before spring barley growing - oat (Avena sativa L.). The field trial was laid out in a randomized single row design with four replicates. Each tilled sub-plot size was $80 \mathrm{~m}^{2}(16.0 \times 5.0 \mathrm{~m})$ of which $29.9 \mathrm{~m}^{2}(13.0 \times 2.3 \mathrm{~m})$ was harvested.

Agronomicpractices. Thepre-crop(springbarley) straw was chopped during harvesting and incorporated into the soil at $6-8 \mathrm{~cm}$ depth during stubble cultivation by using a combined stubble cultivator, equipped with sweeps, discs and a roller. Post-harvest cover crops were sown after stubble cultivation. Deep ploughing (DP) was carried out with a mouldboard plough, ploughless tillage (PT and PT + LS) by a combined stubble cultivator. Lime sludge $\left(7.0 \mathrm{t} \mathrm{ha}^{-1}\right)$ was incorporated into the soil during ploughless tillage operation (PT + LS). Lime sludge was incorporated three times through all rotation for spring crops during the first stage of experiment (2007-2010) and once per rotation for spring barley in the second stage of experiment (2011-2014). Cover crop for winter mulch (NT + WM) was left without any tillage in the autumn and its frost killed residues covered the soil. A field pea cultivar 'Tinker' was grown. It was sown at a rate of 1.2 million seed $\mathrm{ha}^{-1}$ by a drill after pre-sowing tillage by a cultivator. Crop fertilization was $\mathrm{N}_{30} \mathrm{P}_{90} \mathrm{~K}_{60}$. The herbicides with selective mode of action were applied in the crop: Stomp 330 EC $1.51 \mathrm{ha}^{-1}$ (a.i. pendimetalin $330 \mathrm{~g} \mathrm{l}^{-1}$ ) + Basagran $4801.0 \mathrm{l} \mathrm{ha}^{-1}$ (a.i. bentazon $480 \mathrm{~g} \mathrm{l}^{-1}$ ). 
Weather conditions. The year of 2014 was distinguished by a warmer winter, wet May and June, very wet August and very dry September (Fig. 1). The winter period from December 2014 to February 2015 was mild. In 2015, meteorological conditions were

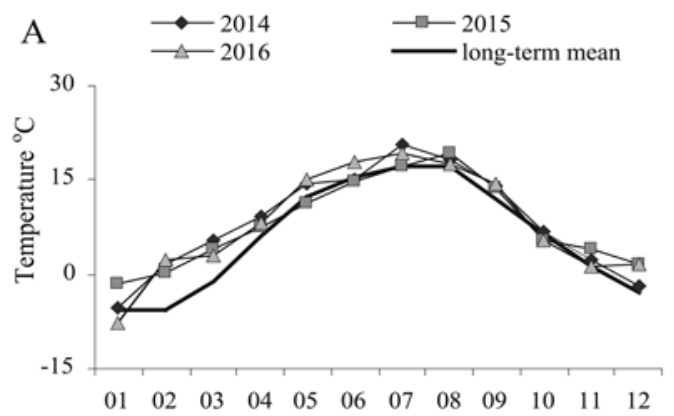

characterised by the wet September and very dry June, August and October. Spring and summer periods in 2016 were warmer than usual. May and September 2016 were very dry, while July and especially August were wet.

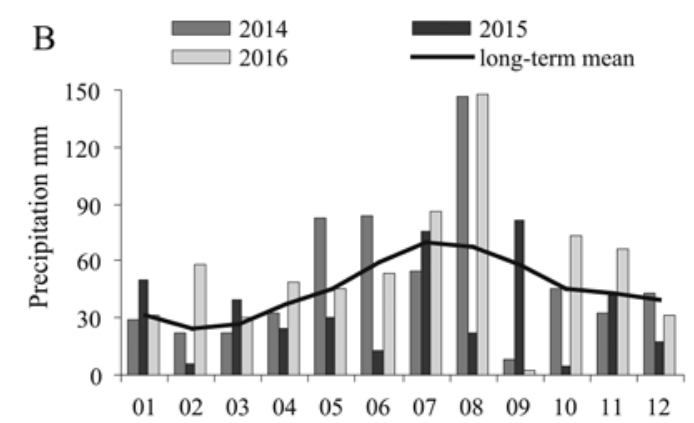

Figure 1. Mean air temperature (A) and amount of precipitation (B) during the study and long-term periods (data from Joniškèlis Experimental Station's meteorological site, 2014-2016)

Analytical methods and assessments. Soil water content was measured before pre-sowing tillage in spring and after full emergence of field pea at $0-15$ and $15-25 \mathrm{~cm}$ depths, and before crop harvesting at $0-15$, $15-25$ and $25-35 \mathrm{~cm}$ depths by drying soil samples at $105^{\circ} \mathrm{C}$ for $48 \mathrm{~h}$. Soil dry bulk density was determined using stainless steel rings $\left(100 \mathrm{~cm}^{3}\right.$ volume $)$ before crop harvesting at $0-5,5-10,10-15,15-20,20-25,25-30$ and $30-35 \mathrm{~cm}$ depths for collection of undisturbed core samples. The cores were oven-dried at $105^{\circ} \mathrm{C}$ for $48 \mathrm{~h}$. The data were averaged for $0-15 \quad 15-25$ and $25-35 \mathrm{~cm}$ depths. Soil water capacity was calculated as follows:

$\mathrm{C}_{\mathrm{v}}=\mathrm{P}_{\mathrm{tv}} / \mathrm{D}$, where $\mathrm{C}_{\mathrm{v}}$ is soil water capacity, \% $(\mathrm{v} / \mathrm{v}), \mathrm{P}_{\mathrm{tv}}-$ soil total porosity, \% (v/v) and D - soil dry bulk density, $\mathrm{Mg} \mathrm{m}^{-3}$.

Soil total porosity was calculated as follows:

$\mathrm{P}_{\mathrm{ty}}=\left(1-\mathrm{D} / \mathrm{D}_{\mathrm{s}}\right) \times 100$, where $\mathrm{P}_{\mathrm{tv}}$ is soil total porosity, $\%$ (v/v), D - soil dry bulk density, $\mathrm{Mg} \mathrm{m}^{-3}$ and $\mathrm{D}_{\mathrm{s}}$ - density of solid soil phase, $\mathrm{Mg} \mathrm{m}^{-3}$.

Soil air-filled porosity was calculated as follows:

$\mathrm{P}=\mathrm{P}_{\mathrm{tV}}-\mathrm{W} \times \mathrm{D}$, where $\mathrm{P}$ is soil air-filled porosity, $\%(\mathrm{v} / \mathrm{v}), \mathrm{P}_{\mathrm{tv}}$ - soil total porosity, \% (v/v), W soil water content, $\%(\mathrm{w} / \mathrm{w})$ and $\mathrm{D}$ - soil dry bulk density, $\mathrm{Mg} \mathrm{m}^{-3}$ (Теории и методы..., 2007).

For distribution of the size of aggregates, the soil was sampled at $0-15$ and $15-25 \mathrm{~cm}$ depths. The soil was air-dried and then sieved into eight size fractions $<0.25$, $0.25-0.5,0.5-1.0,1.0-2.0,2.0-4.0,4.0-5.6,5.6-8.0$ and $>8.0 \mathrm{~mm}$ diameter using a Retsch sieve shaker. Aggregate stability of soil was determined at $0-15$ and $15-25 \mathrm{~cm}$ depths by using a wet sieving apparatus (Eijkelkamp Agrisearch Equipment, The Netherlands). The air-dried soil aggregates (1-2 mm size) are wet sieved in distilled water and then stable aggregates are destroyed by $0.2 \%$ $\mathrm{NaOH}$ solution, oven-dried at $105^{\circ} \mathrm{C}$ for $24 \mathrm{~h}$ and weighed (Al-Kaisi et al., 2014).

All results are based on four soil sample replicates. The results were processed by the analysis of variance (ANOVA) using the software STAT-ENG (Tarakanovas, Raudonius, 2003).

\section{Results and discussion}

Soil water content. The assessments of soil water content in all investigated soil layers before pre-sowing tillage for field pea in spring, after crop emergence and before field pea harvesting did not yield any significant relationships between different conditions of individual research years and methods of tillage applied, thus the results of soil water content changes are evaluated according to the mean data for 2014-2016 (Figs 2 and 3).

According to the mean data of 2014-2016, no significant differences of soil water content in the upper $(0-15 \mathrm{~cm})$ topsoil layer before pre-sowing tillage for field pea in spring were established while applying different autumn tillage methods (Fig. 2).

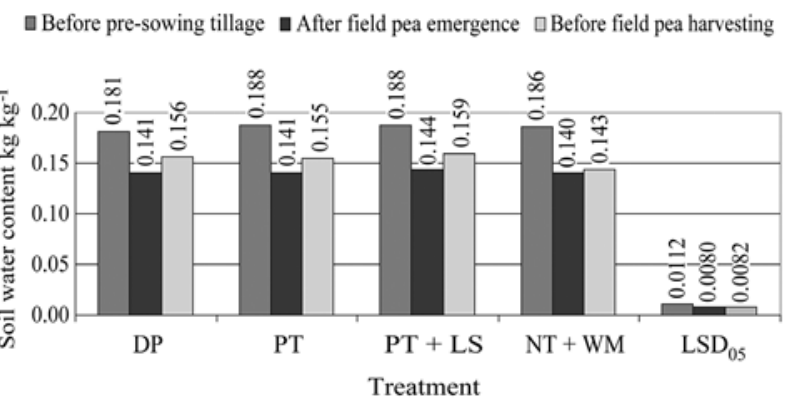

Interaction of treatment and year $F$-act.: before pre-sowing tillage -0.69 , after field pea emergence -1.50 , before field pea harvesting - 0.76; DP - deep ploughing, PT - ploughless tillage, PT + LS - ploughless tillage with lime sludge, NT + $\mathrm{WM}$ - no-till with winter mulch

Figure 2. Soil water content in $0-15 \mathrm{~cm}$ depth under different tillage and supplementary agronomic practices (mean for 2014-2016)

Soil water content before pre-sowing tillage in the lower $(15-25 \mathrm{~cm})$ topsoil layer was significantly influenced by autumn tillage methods. Due to NT + WM, $\mathrm{PT}$ and PT $+\mathrm{LS}$, the soil water content in this layer was significantly higher by $8.2,7.7$ and $7.7 \%$, respectively compared to DP (Fig. 3). No significant differences of soil water content in the upper $(0-15 \mathrm{~cm})$ topsoil layer after field pea emergence were established while applying different autumn tillage (Fig. 2). Having applied NT + $\mathrm{WM}$ and PT $+\mathrm{LS}$, the lower $(15-25 \mathrm{~cm})$ topsoil layer was significantly dryer by $8.9 \%$ and $8.3 \%$, respectively compared to DP (Fig. 3). Soil water content after field pea emergence in both upper $(0-15 \mathrm{~cm})(r=0.78, \mathrm{y}=0.12$ $+0.003 \mathrm{x}, P<0.01)$ and lower $(15-25 \mathrm{~cm})(r=0.88, \mathrm{y}$ $=0.14+0.003 \mathrm{x}, P<0.01)$ topsoil layers was strongly influenced by the amount of rainfall during the ten-day period before field pea emergence. 
$\square$ Before pre-sowing tillage $\square$ After field pea emergence $\square$ Before field pea harvesting

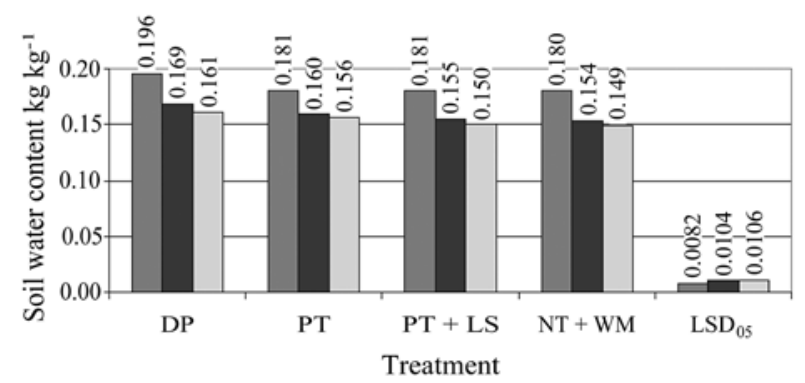

Interaction of treatment and year $F$-act.: before pre-sowing tillage -0.14 , after field pea emergence -1.71 , before field pea harvesting - 1.39; DP - deep ploughing, PT - ploughless tillage, PT + LS - ploughless tillage with lime sludge, NT + $\mathrm{WM}$ - no-till with winter mulch

Figure 3. Soil water content in 15-25 cm depth under different tillage and supplementary agronomic practices (mean for 2014-2016)

Application of NT + WM demonstrated significantly lower soil water content before field pea harvesting in both upper $(0-15 \mathrm{~cm})$ and lower $(15-$ $25 \mathrm{~cm}$ ) layers by $8.3 \%$ and $7.5 \%$, respectively compared to DP (Figs 2 and 3). Application of PT + LS resulted in significantly drier $15-25 \mathrm{~cm}$ topsoil layer before field pea harvesting by $6.8 \%$ compared to DP.

Soil water capacity. The influence of tillage on the soil water capacity did not depend on the conditions of individual years. According to the mean data of 2014 2016, no significant differences in soil water capacity in the upper $(0-15 \mathrm{~cm})$ topsoil layer were established while applying different autumn tillage methods (Fig. 4). Soil water capacity decreased significantly by $5.9,4.9$ and $4.1 \%$ in the lower $(15-25 \mathrm{~cm})$ topsoil layer and it increased by $6.5,10.6$ and $6.1 \%$, respectively in the subsoil $(25-35 \mathrm{~cm})$ layer after the application of PT, PT $+\mathrm{LS}$ and NT + WM compared to DP.

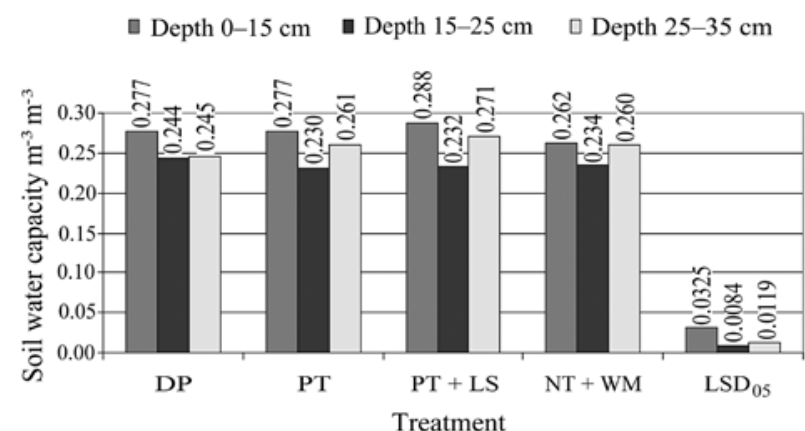

Interaction of treatment and year $F$-act: $0-15 \mathrm{~cm}-1.51$, 15-25 cm - 0.12, 25-35 cm - 0.33; DP - deep ploughing, PT - ploughless tillage, PT + LS - ploughless tillage with lime sludge, NT + WM - no-till with winter mulch

Figure 4. Soil water capacity under different tillage and supplementary agronomic practices (mean for 2014-2016)

Soil moisture management is an important condition for maintenance of soil quality. The research carried out on the loamy soils in Central Lithuania indicates that reduced tillage and no-till in dry conditions are superior to conventional tillage due to greater soil water content accumulated in the upper topsoil layers after sowing the spring crops. However, in deeper topsoil layers water content under no-till was essentially lower during later crop growing period (Feiza et al., 2011). Romaneckas et al. (2009) have reported that reduction of silty loam tillage intensity, especially no-till increased soil water content in the upper topsoil layer before presowing tillage and after crop sowing; however, it had no significant influence in deeper layers compared to conventional ploughing. Depth and quality of the tillage have great influence on soil moisture management (Birkas et al., 2007). Both depth of the loosened layer and the surface state (friability, cover) are the most important factors that predetermine moisture management in the growing season. A review by Soane et al. (2012) of no-till in northern, western and south-western Europe concluded that in northern regions no-till usually allows earlier drilling of winter crops but will give higher soil moisture content in spring, causing delayed drilling of spring crops. Moreover, no-till soils have greater bulk density and bearing capacity than ploughed soils allowing penetration of roots and water. Therefore, ploughing is still very widely adopted and effective method of seedbed preparation on poorly drained soils in wetter regions of northern Europe because it can provide topsoil surface aeration and drainage especially in spring, and remediate surface compaction.

Soil dry bulk density. The conditions of certain years did not determine the influence of the investigated tillage on the soil dry bulk density in all topsoil and subsoil layers. According to the mean data of 2014-2016, no significant differences of soil dry bulk density in the upper $(0-15 \mathrm{~cm})$ topsoil layer before field pea harvesting were established while applying different autumn tillage (Table 1). It was established that due to PT the soil dry bulk density in the lower $(15-25 \mathrm{~cm})$ topsoil layer was significantly higher by $1.8 \%$ compared to DP. However, the application of PT, PT + LS and NT + WM demonstrated significantly lower soil dry bulk density in the subsoil $(25-35 \mathrm{~cm})$ layer by $2.5,3.7$ and $2.5 \%$, respectively compared to DP.

Soil total porosity. The influence of certain years on the soil total porosity was not observed. According to the mean data of 2014-2016, no significant differences of soil total porosity in the upper $(0-15 \mathrm{~cm})$ topsoil layer before field pea harvesting were established while applying different autumn tillage methods (Table 2). Soil total porosity in the lower $(15-25 \mathrm{~cm})$ topsoil layer decreased significantly by $3.1 \%$ and $2.3 \%$, respectively after PT and PT + LS had been applied compared to DP. The application of PT, PT $+\mathrm{LS}$ and NT $+\mathrm{WM}$ determined significantly higher soil total porosity in the subsoil $(25-35 \mathrm{~cm})$ layer by $3.5,6.0$ and $3.3 \%$, respectively compared to DP.

Soil air-filled porosity. The assessments of soil air-filled porosity before field pea harvesting did not yield any significant relationship between different research year conditions and methods of tillage applied. According to the mean data of 2014-2016, no significant differences of soil air-filled porosity in the upper $(0-15 \mathrm{~cm})$ topsoil layer were established while applying different autumn tillage methods (Table 3). A significantly higher by $19.0 \%$ soil air-filled porosity was achieved in the lower $(15-25 \mathrm{~cm})$ topsoil layer due to PT + LS and in the subsoil $(25-35 \mathrm{~cm})$ layer by $18.5,29.6$ and $24.1 \%$, respectively due to PT, PT + LS and NT + WM compared with DP.

Tillage and rotation are fundamental factors influencing soil quality and sustainability of cropping systems. In the study by Feiza et al. (2011), soil physical properties depended on tillage intensity and soil depth. 
Table 1. Soil dry bulk density $\left(\mathrm{Mg} \mathrm{m}^{-3}\right)$ under different tillage and supplementary agronomic practices

\begin{tabular}{|c|c|c|c|c|c|}
\hline \multirow{2}{*}{ Treatment } & \multirow{2}{*}{$\begin{array}{c}\text { Depth } \\
\text { cm }\end{array}$} & \multicolumn{3}{|c|}{ Year } & \multirow{2}{*}{ Mean } \\
\hline & & 2014 & 2015 & 2016 & \\
\hline \multirow{3}{*}{ Deep ploughing (DP) } & $0-15$ & 1.53 & 1.51 & 1.57 & 1.54 \\
\hline & $15-25$ & 1.62 & 1.62 & 1.64 & 1.63 \\
\hline & $25-35$ & 1.65 & 1.61 & 1.63 & 1.63 \\
\hline \multirow{3}{*}{ Ploughless tillage (PT) } & $0-15$ & 1.52 & 1.52 & 1.57 & 1.54 \\
\hline & $15-25$ & 1.65 & 1.63 & $1.70^{*}$ & $1.66^{*}$ \\
\hline & $25-35$ & 1.59 & 1.55 & 1.63 & $1.59^{*}$ \\
\hline \multirow{3}{*}{ Ploughless tillage with lime sludge $(\mathrm{PT}+\mathrm{LS})$} & $0-15$ & 1.50 & 1.45 & 1.56 & 1.50 \\
\hline & $15-25$ & 1.65 & 1.62 & 1.69 & 1.65 \\
\hline & $25-35$ & 1.58 & $1.53 *$ & 1.59 & $1.57 *$ \\
\hline \multirow{3}{*}{ No-till with winter mulch $(\mathrm{NT}+\mathrm{WM})$} & $0-15$ & $1.64 *$ & 1.52 & 1.57 & 1.58 \\
\hline & $15-25$ & 1.65 & 1.64 & 1.67 & 1.65 \\
\hline & $25-35$ & 1.60 & 1.55 & 1.63 & $1.59^{*}$ \\
\hline \multirow{3}{*}{$\mathrm{LSD}_{05}$} & $0-15$ & 0.088 & 0.074 & 0.067 & 0.069 \\
\hline & $15-25$ & 0.098 & 0.089 & 0.054 & 0.027 \\
\hline & $25-35$ & 0.084 & 0.066 & 0.056 & 0.032 \\
\hline
\end{tabular}

Interaction of treatment and year $F$-act.: $0-15 \mathrm{~cm}-1.80,15-25 \mathrm{~cm}-0.37,25-35 \mathrm{~cm}-0.33$

* - significant at $p \leq 0.05$

Table 2. Soil total porosity $\left(\mathrm{m}^{-3} \mathrm{~m}^{-3}\right)$ under different tillage and supplementary agronomic practices

\begin{tabular}{|c|c|c|c|c|c|}
\hline \multirow{2}{*}{ Treatment } & \multirow{2}{*}{$\begin{array}{c}\text { Depth } \\
\mathrm{cm}\end{array}$} & \multicolumn{3}{|c|}{ Year } & \multirow{2}{*}{ Mean } \\
\hline & & 2014 & 2015 & 2016 & \\
\hline \multirow{3}{*}{ Deep ploughing (DP) } & $0-15$ & 0.427 & 0.429 & 0.413 & 0.423 \\
\hline & $15-25$ & 0.396 & 0.396 & 0.388 & 0.393 \\
\hline & $25-35$ & 0.391 & 0.408 & 0.397 & 0.399 \\
\hline \multirow{3}{*}{ Ploughless tillage (PT) } & $0-15$ & 0.429 & 0.429 & 0.411 & 0.423 \\
\hline & $15-25$ & 0.384 & 0.391 & $0.367^{*}$ & $0.381 *$ \\
\hline & $25-35$ & 0.413 & 0.429 & 0.398 & $0.413^{*}$ \\
\hline \multirow{3}{*}{ Ploughless tillage with lime sludge (PT + LS) } & $0-15$ & 0.437 & 0.457 & 0.403 & 0.432 \\
\hline & $15-25$ & 0.387 & 0.395 & 0.370 & $0.384 *$ \\
\hline & $25-35$ & 0.419 & $0.436^{*}$ & 0.415 & $0.423 *$ \\
\hline \multirow{3}{*}{ No-till with winter mulch $(\mathrm{NT}+\mathrm{WM})$} & $0-15$ & $0.387 *$ & 0.431 & 0.413 & 0.410 \\
\hline & $15-25$ & 0.384 & 0.393 & 0.379 & 0.385 \\
\hline & $25-35$ & 0.409 & 0.428 & 0.399 & $0.412 *$ \\
\hline \multirow{3}{*}{$\mathrm{LSD}_{05}$} & $0-15$ & 0.0329 & 0.0283 & 0.0279 & 0.0306 \\
\hline & $15-25$ & 0.0368 & 0.0346 & 0.0194 & 0.0090 \\
\hline & $25-35$ & 0.0306 & 0.0246 & 0.0208 & 0.0106 \\
\hline
\end{tabular}

Interaction of treatment and year $F$-act.: $0-15 \mathrm{~cm}-1.55,15-25 \mathrm{~cm}-0.15,25-35 \mathrm{~cm}-0.30$

* - significant at $p \leq 0.05$

Table 3. Soil air-filled porosity $\left(\mathrm{m}^{-3} \mathrm{~m}^{-3}\right)$ under different tillage and supplementary agronomic practices

\begin{tabular}{|c|c|c|c|c|c|}
\hline \multirow{2}{*}{ Treatment } & \multirow{2}{*}{$\begin{array}{c}\text { Depth } \\
\text { cm }\end{array}$} & \multicolumn{3}{|c|}{ Year } & \multirow{2}{*}{ Mean } \\
\hline & & 2014 & 2015 & 2016 & \\
\hline \multirow{3}{*}{ Deep ploughing (DP) } & $0-15$ & 0.210 & 0.190 & 0.156 & 0.185 \\
\hline & $15-25$ & 0.164 & 0.105 & 0.094 & 0.121 \\
\hline & $25-35$ & 0.108 & 0.128 & 0.088 & 0.108 \\
\hline \multirow{3}{*}{ Ploughless tillage (PT) } & $0-15$ & 0.209 & 0.189 & 0.156 & 0.185 \\
\hline & $15-25$ & 0.162 & 0.121 & 0.102 & 0.128 \\
\hline & $25-35$ & $0.150^{*}$ & 0.139 & 0.096 & $0.128 *$ \\
\hline \multirow{3}{*}{ Ploughless tillage with lime sludge (PT + LS) } & $0-15$ & 0.218 & 0.221 & 0.153 & 0.197 \\
\hline & $15-25$ & 0.169 & $0.151^{*}$ & 0.111 & $0.144 *$ \\
\hline & $25-35$ & $0.151^{*}$ & 0.154 & $0.115^{*}$ & $0.140 *$ \\
\hline \multirow{3}{*}{ No-till with winter mulch $(\mathrm{NT}+\mathrm{WM})$} & $0-15$ & 0.169 & 0.223 & 0.164 & 0.185 \\
\hline & $15-25$ & 0.167 & $0.153^{*}$ & 0.107 & 0.142 \\
\hline & $25-35$ & $0.147^{*}$ & 0.157 & 0.098 & $0.134 *$ \\
\hline \multirow{3}{*}{$\mathrm{LSD}_{05}$} & $0-15$ & 0.0453 & 0.0430 & 0.0341 & 0.0387 \\
\hline & $15-25$ & 0.0452 & 0.0381 & 0.0287 & 0.0221 \\
\hline & $25-35$ & 0.0174 & 0.0341 & 0.0153 & 0.0184 \\
\hline
\end{tabular}

Interaction of treatment and year $F$-act.: $0-15 \mathrm{~cm}-1.45,15-25 \mathrm{~cm}-0.29,25-35 \mathrm{~cm}-0.57$

\footnotetext{
* - significant at $p \leq 0.05$
} 
Consequently, the best physical quality on loam soil was recorded under conventional and reduced tillage, while on sandy loam the conventional tillage had an advantage over reduced tillage and no-till. The findings of Bogužas et al. (2010) revealed that no significant differences of clay loam soil bulk density vs. conventional ploughing at 23-25 cm depth were obtained in reduced autumn tillage - shallow ploughing at $10-12 \mathrm{~cm}$ depth and ploughless tillage at 8-10 cm depth. Myrbeck et al. (2012) concluded that no significant changes in medium clay soil physical parameters were detected after tillage in late autumn compared with early autumn. The studies carried out by Crittenden et al. (2015) indicate that increased soil bulk density under reduced tillage conditions can delay soil water transmission and can be detrimental to crops sensitive to soil compaction. Investigations in a longterm field experiment in Switzerland showed that soil air- filled porosity under mouldboard ploughing was higher than in no-till in the topsoil, but lower in the subsoil (Martinez et al., 2016). As pointed out by Arvidsson et al. (2013), decreasing non-inversion tillage depth generally increased penetration resistance and reduced saturated hydraulic conductivity in the topsoil, which is considered as negative for crop growth.

Soil aggregate composition and aggregate stability. In our research, the conditions of certain years did not determine the influence of tillage on the changes in the amount of most agronomically valuable $(0.25$ $5.6 \mathrm{~mm}$ ) soil aggregates and in the amount of stable soil aggregates in the topsoil layers. According to the mean data of 2014-2016, amounts of stable soil aggregates in the upper $(0-15 \mathrm{~cm})$ topsoil layer decreased significantly by $19.4 \%$ only after NT + WM had been applied compared to DP (Table 4).

Table 4. Amount $\left(\mathrm{kg} \mathrm{kg}^{-1}\right)$ of agronomically valuable $(0.25-5.6 \mathrm{~mm})$ soil aggregates under different tillage and supplementary agronomic practices

\begin{tabular}{cccccc}
\hline \multirow{2}{*}{ Treatment } & Depth & \multicolumn{3}{c}{ Year } & \multirow{2}{*}{ Mean } \\
\cline { 3 - 5 } & $\mathrm{cm}$ & 2014 & 2015 & 2016 & \\
\hline \multirow{2}{*}{ Deep ploughing (DP) } & $0-15$ & 0.537 & 0.568 & 0.470 & 0.525 \\
& $15-25$ & 0.351 & 0.342 & 0.215 & 0.303 \\
\hline \multirow{2}{*}{ Ploughless tillage (PT) } & $0-15$ & 0.553 & 0.527 & 0.421 & 0.500 \\
& $15-25$ & 0.355 & 0.317 & $0.321^{*}$ & 0.331 \\
\hline \multirow{2}{*}{ Ploughless tillage with lime sludge (PT + LS) } & $0-15$ & 0.551 & 0.559 & 0.414 & 0.508 \\
& $15-25$ & 0.353 & 0.291 & $0.344^{*}$ & 0.329 \\
\hline \multirow{2}{*}{ No-till with winter mulch (NT + WM) } & $0-15$ & $0.449^{*}$ & $0.439^{*}$ & 0.380 & $0.423^{*}$ \\
\hline \multirow{2}{*}{ LSD $_{05}$} & $15-25$ & $0.414^{*}$ & 0.271 & $0.360^{*}$ & 0.348 \\
\hline
\end{tabular}

Interaction of treatment and year $F$-act.: $0-15 \mathrm{~cm}-0.33,15-25 \mathrm{~cm}-2.27$

* - significant at $p \leq 0.05$

Application of PT + LS resulted in significantly higher amount of stable soil aggregates by $11.7 \%$ and $11.2 \%$, respectively in the both upper $(0-15 \mathrm{~cm})$ and lower (15-25 cm) topsoil layers compared to DP (Table 5).

Soil structure varies considerably with time, as a result of complex interactions between soil management and environmental factors. Soil structure forms by natural and tillage induced processes. A review by Birkas et al. (2007) have concluded that primary factors which cause clod or dust formation and deteriorate the aggregation are: (1) soil compaction and re-compaction, (2) soil drying after harvest, (3) over aeration of soils during primary tillage

Table 5. Amount $\left(\mathrm{kg} \mathrm{kg}^{-1}\right)$ of stable soil aggregates under different tillage and supplementary agronomic practices

\begin{tabular}{|c|c|c|c|c|c|}
\hline \multirow{2}{*}{ Treatment } & \multirow{2}{*}{$\begin{array}{c}\text { Depth } \\
\mathrm{cm}\end{array}$} & \multicolumn{3}{|c|}{ Year } & \multirow{2}{*}{ Mean } \\
\hline & & 2014 & 2015 & 2016 & \\
\hline \multirow{2}{*}{ Deep ploughing (DP) } & $0-15$ & 0.702 & 0.728 & 0.650 & 0.693 \\
\hline & $15-25$ & 0.647 & 0.788 & 0.619 & 0.685 \\
\hline \multirow{2}{*}{ Ploughless tillage (PT) } & $0-15$ & 0.667 & 0.742 & $0.675^{*}$ & 0.695 \\
\hline & $15-25$ & 0.667 & $0.839 *$ & $0.693 *$ & 0.733 \\
\hline \multirow{2}{*}{ Ploughless tillage with lime sludge $(\mathrm{PT}+\mathrm{LS})$} & $0-15$ & 0.765 & $0.787^{*}$ & $0.769^{*}$ & $0.774^{*}$ \\
\hline & $15-25$ & $0.788^{*}$ & 0.796 & $0.702 *$ & $0.762 *$ \\
\hline \multirow{2}{*}{ No-till with winter mulch (NT + WM) } & $0-15$ & 0.725 & $0.821^{*}$ & 0.669 & 0.738 \\
\hline & $15-25$ & 0.717 & $0.843 *$ & $0.665^{*}$ & 0.742 \\
\hline \multirow{2}{*}{$\mathrm{LSD}_{05}$} & $0-15$ & 0.0941 & 0.0428 & 0.0241 & 0.0617 \\
\hline & $15-25$ & 0.1183 & 0.0436 & 0.0453 & 0.0767 \\
\hline
\end{tabular}

Interaction of treatment and year $F$-act.: $0-15 \mathrm{~cm}-1.54,15-25 \mathrm{~cm}-1.48$

* - significant at $p \leq 0.05$

and (4) soil drying at primary tillage (before seedbed preparation). They stated that structure deterioration may extend by the use of water and carbon loss tillage in a long-term. Intensive tillage and traffic in unfavourable conditions (too wet or too dry soil) may result in negative effect on soil fragmentation and friability (Munkholm, 2011). As pointed out by Keller et al. (2007), soils with poorer physical quality produce large amounts of clods.
Thus, no clods $>50 \mathrm{~mm}$ were produced in soils when they were ploughed at the optimum water content for tillage. Al-Kaisi et al. (2014) emphasize that the increase in large aggregates in no-till soils is the result of the presence of large amounts of crop residue on the soil surface and minimum soil disturbance, which facilitates soil structural stability. They also pointed out that no-till system creates better soil conditions for stabilization and protection of 
macroaggregates $(>0.50 \mathrm{~mm})$ when the wetting process continues for a long time, while microaggregates $(0.053$ $0.50 \mathrm{~mm}$ ) are less influenced by the type of tillage system. The studies carried out by Sheehy et al. (2015) indicate that aggregate size decreased in the order of no-tillage $>$ reduced tillage $>$ conventional tillage. Munkholm et al. (2013) emphasize that no-till has led to a poor silt loam soil structure and they conclude that a diverse crop rotation is needed for an optimal implementation of no-till for such soil. Rücknagel et al. (2016) found that catch crop cultivation only rarely positively affected soil structure and catch crops did not contribute in the short term to loosening already compacted medium textured silty loam topsoil. Consequently, deep ploughless tillage was more effective at loosening compacted topsoil than catch crop cultivation. Hontoria et al. (2016) found that no-till increased the macroaggregates to a depth of $10 \mathrm{~cm}$ by about $40 \%$ compared with traditionally tilled plots, while the effect of Ca-amendment on aggregation was much smaller than that of the tillage system. They pointed out that Ca-amendment of non-till plots improved some parameters related to aggregation. Bogužas et al. (2010) points out increased amount of stable aggregates in both $0-15$ and $15-25 \mathrm{~cm}$ soil layers under reduced and no-till compared to deep ploughing. Crittenden et al. (2015) observed an increase of soil aggregate stability at $10-20 \mathrm{~cm}$ depth when reduced (non-inversion) tillage was used on a calcareous marine clay loam compared to mouldboard ploughing in both organic and conventional farming fields.

\section{Conclusions}

1. Application of no-till in autumn with a cover crop for winter mulch, ploughless tillage alone and ploughless tillage with lime sludge incorporation significantly increased the soil water content in the lower $(15-25 \mathrm{~cm})$ topsoil layer before pre-sowing tillage for field pea in spring compared to deep ploughing.

2. Application of no-till in the autumn with a cover crop for winter mulch and ploughless tillage with lime sludge incorporation resulted in significantly lower soil water content after field pea emergence in the lower $(15-25 \mathrm{~cm})$ topsoil layer compared to deep ploughing.

3. No-till in the autumn with a cover crop for winter mulch demonstrated significantly lower soil water content before field pea harvesting in both upper $(0-15 \mathrm{~cm})$ and lower $(15-25 \mathrm{~cm})$ topsoil layers, while incorporation of lime sludge by ploughless tillage decreased soil water content in the lower topsoil layer compared to deep ploughing.

4. Soil water capacity decreased significantly in the lower topsoil layer and it increased in the subsoil (25$35 \mathrm{~cm}$ ) layer after the application of ploughless tillage alone, ploughless tillage with lime sludge incorporation and no-till in the autumn with a cover crop for winter mulch compared to deep ploughing.

5. Due to the ploughless tillage alone, soil dry bulk density increased and soil total porosity decreased significantly in the lower topsoil layer before crop harvesting, while the application of ploughless tillage with lime sludge incorporation, ploughless tillage alone and no-till in the autumn with a cover crop for winter mulch demonstrated significantly lower soil dry bulk density and higher total porosity in the subsoil compared to deep ploughing. Incorporation of lime sludge (Ca-amendment) by ploughless tillage significantly increased the soil airfilled porosity in the lower topsoil layer as compared to deep ploughing. Reduced ploughless and no-till also increased the soil air-filled porosity in the subsoil.

6. Use of no-till in the autumn with a cover crop for winter mulch resulted in significantly lower amount of most agronomically valuable $(0.25-5.6 \mathrm{~mm})$ soil aggregates in the upper topsoil layer before crop harvesting, while incorporation of lime sludge by ploughless tillage demonstrated significantly higher amount of stable soil aggregates in both upper and lower topsoil layers compared to deep ploughing.

\section{Acknowledgements}

This work was supported by the National Science Program "The effect of long-term, different-intensity management of resources on the soils of different genesis and on other components of the agro-ecosystems" (grants No. SIT-9/2015) funded by the Research Council of Lithuania.

Received 26072017

Accepted 27112017

\section{References}

1. Al-Kaisi M. M., Douelle A., Kwaw-Mensah D. 2014. Soil microaggregate and macroaggregate decay over time and soil carbon change as influenced by different tillage systems. Soil and Water Conservation. 69: 574-580. https://doi.org/10.2489/jswc.69.6.574

2. Arvidsson J., Westlin A., Sorensson F. 2013. Working depth in non-inversion tillage - effects on soil physical properties and crop yield in Swedish field experiments. Soil and Tillage Research. 126: 259-266. https://doi.org/10.1016/j.still.2012.08.010

3. Birkas M., Kalmar T., Bottlik L., Takacs T. 2007. Importance of soil quality in environment protection. Agriculturae Conspectus Scientificus, 72 (1): 21-26.

4. Bogužas V., Kairytė A., Jodaugienè D. 2010. Soil physical properties and earthworms as affected by soil tillage systems, straw and green manure management. ZemdirbysteAgriculture, 97 (3): 3-14.

5. Crittenden S. J., Poot N., Heinen M., Van Balen D. J. M., Pulleman M. M. 2015. Soil physical quality in contrasting tillage systems in organic and conventional farming. Soil and Tillage Research. 154: 136-144. https://doi.org/10.1016/j.still.2015.06.018

6. Derpsch R., Friedricg T., Kassam A., Hongwen L. 2010. Current status of adoption of no-till farming in the world and some of its main benefits. International Journal of Agricultural and Biological Engineering, 3 (1): 1-25.

7. Feiza V., Feiziene D., Kadziene G., Lazauskas S., Deveikyte I., Slepetiene A., Seibutis V. 2011. Soil state in the $11^{\text {th }}$ year of three tillage systems application on a Cambisol. Journal of Food, Agriculture and Environment, $9(3-4)$ : 1088-1095.

8. Hontoria C., Gomez-Paccard C., Mariscal-Sancho I., Benito M., Perez J., Espejo R. 2016. Aggregate size distribution and associated organic $\mathrm{C}$ and $\mathrm{N}$ under different tillage systems and Ca-amendment in a degraded Ultisol. Soil and Tillage Research, 160: 42-52. https://doi.org/10.1016/j.still.2016.01.003

9. Keller T., Arvidsson J., Dexter A. R. 2007. Soil structures produced by tillage as affected by soil water content and the physical quality of soil. Soil and Tillage Research, 92: 45-52. https://doi.org/10.1016/j.still.2006.01.001

10. Martinez I., Chervet A., Weisskopf P., Sturny W. G., Rek J., Keller T. 2016. Two decades of no-till in the Oberacker longterm field experiment. Part II. Soil porosity and gas transport parameters. Soil and Tillage Research, 163: 130-140. https://doi.org/10.1016/j.still.2016.05.020 
11. Morris N.L., Miller P.C.H., Orson J.H.,Froud-Williams R. J. 2010. The adoption of non-inversion tillage systems in the United Kingdom and the agronomic impact on soil, crops and the environment - a review. Soil and Tillage Research, 108: 1-15. https://doi.org/10.1016/j.still.2010.03.004

12. Munkholm L. J. 2011. Soil friability: a review of the concept, assessment and effects of soil properties and management. Geoderma. 167-168: 236-246. https://doi.org/10.1016/j.geoderma.2011.08.005

13. Munkholm L. J., Heck R. J., Denn B. 2013. Long-term rotation and tillage effects on soil structure and crop yield. Soil and Tillage Research. 127: 85-91. https://doi,org/10.1016/j.still.2012.02.007

14. Myrbeck A., Stenberg M., Arvidsson J., Rydberg T. 2012. Effects of autumn tillage of clay soil on mineral $\mathrm{N}$ content, spring cereal yield and soil structure over time. European Journal of Agronomv. 37 (1): 96-104. https://doi.org/10.1016/j.eja.2011.11.007

15. Ožeraitienè D., Čiuberkis S. 2006. The effect of different tillage methods and organic fertilizers on soil physical state and crop yield. Zemdirbyste-Agriculture, 93 (4): 180-189.

16. Riley H., Borresen T., Lindemark P. O. 2009. Recent yield results and trends over time with conservation tillage on clay loam and silt loam soils in southeast Norway. Acta Agriculturae Scandinavica, Section B: Plant Soil Science, 59 (4): 362-372. https://doi.org/10.1080/09064710802263200

17. Romaneckas K., Romaneckienė R., S̈arauskis E., Pilipavičius V., Sakalauskas A. 2009. The effect of conservation primary and zero tillage on soil bulk density, water content, sugar beet growth and weed infestation. Agronomy Research, 7 (1): 73-86.
18. Rücknagel J., Götze P., Koblenz B., Bachmann N., Löbner S., Lindner S., Bischoff J., Christen O. 2016. Impact of soil physical properties of using large-grain legumes for catch crop cultivation under different tillage conditions. Euronean Journal of Agronomy, 77: 28-37. https://doi.org/10.1016/j.eja.2016.03.010

19. Sheehy J., Regina K., Alakukku L., Six J. 2015. Impact of no-till and reduced tillage on aggregation and aggregateassociated carbon in Northern European agroecosystems. Soil and Tillage Research. 150: 107-113. https://doi.org/10.1016/j.still.2015.01.015

20. Soane B. D., Ball B. C., Arvidsson J., Basch G., Moreno F., Roger-Estrade J. 2012. No-till in northern, western and south-western Europe: a review of problems and opportunities for crop production and the environment. Soil and Tillage Research, 118: 66-87. https://doi.org/10.1016/j.still.2011.10.015

21. Sustainable agriculture on productive soils. 2008 / compiled by Maikštėnienė S. Lithuanian Institute of Agriculture, 344 p. (in Lithuanian).

22. Tarakanovas P., Raudonius S. 2003. Agronominiu tyrimu duomenų statistinè analizè taikant kompiuterines programas ANOVA, STAT, SPLIT-PLOT iš paketo SELEKCIJA ir IRRISTAT. Lithuanian University of Agriculture, $58 \mathrm{p}$. (in Lithuanian).

23. Van den Putte A., Govers G., Diels J., Gillijns K., Demuzere M. 2010. Assessing the effect of soil tillage on crop growth: a meta-regression analysis on European crop yields under conservation agriculture. Euronean Journal of Agronomy, 33 (3): 231-241. https://doi.org/10.1016/j.eja.2010.05.008

24. Теории и методы физики почвы. 2007 / compiled by Shein E. B., Karpachevskij L. O. Tula, Russia, 616 p. (in Russian).

ISSN 1392-3196 / e-ISSN 2335-8947

Zemdirbyste-Agriculture, vol. 105, No. 1 (2018), p. 3-10

DOI $10.13080 /$ z-a.2018.105.001

\title{
Žemès dirbimo, kalkių purvo ir tarpinio pasèlio poveikis sunkaus priemolio dirvožemio fizinei būklei
}

\author{
A. Velykis, A. Satkus
}

Lietuvos agrarinių ir miškų mokslų centro Joniškèlio bandymų stotis

\begin{abstract}
Santrauka
Molingų dirvožemių fizinès būklès pokyčius lemia dirvožemio tipas, drègnis, oro sąlygos ir žemès dirbimo intensyvumas. Lietuvoje galimybės supaprastinti molingų žemių dirbimą nẻra pakankamai ištirtos. Tyrimai atlikti 2014-2016 m. Lietuvos agrarinių ir miškų mokslu centro Joniškèlio bandymų stotyje giliau karbonatiniame giliau glèjiškame sunkaus priemolio rudžemyje (RDg4-k2), $2006 \mathrm{~m}$. įrengtame lauko eksperimente. Tyrimų tikslas ivvertinti ilgalaikio ịvairaus intensyvumo žemès dirbimo ir kitu papildomų priemonių: gilaus arimo $21-23 \mathrm{~cm}$ gyliu bei seklaus bearimio žemės dirbimo $10-12 \mathrm{~cm}$ gyliu ir seklaus bearimio žemės dirbimo, kartu įterpiant kalkiu purvą, ir visai be žemės dirbimo rudeni paliekant tarpini paselị mulčiui per žiemą, poveiki dirvožemio fizinès būklès rodikliams, nustatytiems žirnių lauke. Bearimis žemès dirbimas lèmè iš esmès didesnị dirvožemio drègni pavasarị priešsejjinio žemès dirbimo metu, didesnị dirvožemio tanki, mažesnius bendraji poringumą ir vandentalpą armenyje prieš derliaus nuėmimą, bet mažesni dirvožemio tankị, didesnę vandentalpą, didesnị bendrajị ir aeracini poringumą poarmenyje, palyginti su giliu arimu. Dèl kalkių purvo ịterpimo derinio su bearimiu dirbimu nustatytas didesnis dirvožemio drẻgnis pavasarị, priešsējinio žemès dirbimo metu, bet mažesnis drègnis po žirnių sudygimo ir prieš derliaus nuėmimą. Šs derinys lèmè didesnị dirvožemio aeracini poringumą ir dirvožemio patvariu struktūrinių trupinẻlių kiekị armenyje, mažesnị tankị, didesnị bendrajị ir aeracinị poringumą poarmenyje prieš derliaus nuėmimą. Tarpinị pasèlį mulčiui palikus žiemai be žemès dirbimo rudenị, iš esmės didesnis dirvožemio drègnis armenyje buvo pavasarị, pradedant priešsējini žemès dirbimą. Dirvožemio drègnis jame sumažėjo žirniams sudygus ir prieš jų derliaus nuėmimą, o poarmenyje sumažejo dirvožemio tankis ir padidèjo bendrasis bei aeracinis poringumas. Tačiau žemès visai nedirbant rudenį, agronomiškai vertingiausių dirvožemio struktūrinių trupinèlių $(0,25-5,6 \mathrm{~mm})$ kiekis armenyje prieš derliaus nuèmimą sumažějo, palyginti su giliu arimu.
\end{abstract}

Reikšminiai žodžiai: arimas, bearimis dirbimas, drègnis ir vandentalpa, mulčias be žemès dirbimo, struktūra, tankis ir poringumas. 